lance Centre and the Scottish Centre for Infection and Environmental Health. NSHPC relies on active reporting from paediatricians through the British Paediatric Surveillance Uni of the Royal College of Paediatrics and Child Health, and from obstetric respondents reporting through an active reporting scheme run under the auspices of the Royal College of Obstetricians and Gynaecologists. We thank all those reporting to NSHPC and particularly the staff, families, and children from the 17 CHIPS centres (see bmj.com for details).

Contributors: See bmj.com

Funding: NSHPC receives support from the Department of Health and the Medical Research Council. The CHIPS cohort has received additional support from Bristol-Myers Squibb, Boehringer Ingelheim, GlaxoSmithKline, Roche, Abbott, and Gilead.

Competing interests: None declared.

Ethical approval: The national study of HIV in pregnancy and childhood received renewed ethics approval, including follow up in the collaborative HIV paediatric study, in 2001 from Great Ormond Street Hospital for Children NHS Trust and the Institute of Child Health research ethics committee.

Guidelines for the use of antiretroviral agents in HIV infected adults and adolescents (accessed 14 July 2003).

British HIV Association (BHIVA). Guidelines for the treatment of HIV infected adults with antiretroviral therapy (accessed 14 July 2003).

3 Mocroft A, Vella S, Benfield TL, Chiesi A, Miller V, Gargalianos P, et al. Changing patterns of mortality across Europe in patients infected with Changing patterns of mortality across Europe in patient

4 Palella FJ Jr, Delaney KM, Moorman AC, Loveless MO, Fuhrer J, Satten $\mathrm{GA}$, et al. Declining morbidity and mortality among patients with advanced human immunodeficiency virus infection. HIV Outpatien Study Investigators. N Engl J Med 1998;338:853-60.
5 Detels R, Munoz A, McFarlane G, Kingsley LA, Margolick JB, Giorgi J, et l. Effectiveness of potent antiretroviral therapy on time to AIDS and death in men with known HIV infection duration. Multicenter AIDS Cohort Study Investigators. JAMA 1998;280:1497-503.

Cohort Study Investigators. JAMA 1998;280:1497-503.
Sharland M, Castelli Gattinara di Zub G, Ramos JT, Blanche S, Gibb DM on behalf of the PENTA Steering Committee. PENTA (Paediatric European Network for Treatment of AIDS) guidelines for the use of antiretroviral therapy in paediatric HIV infection. HIV Med 2002;3:215-26.

7 Working Group on Antiretroviral Therapy, Medical Management of HIV-infected Children convened by National Pediatric and Family HIV Resource Center, Health Resources and Services Administration, and National Institutes of Health. Guidelines for the use of antiretroviral agents in pediatric HIV infection. 2001 (accessed 22 Sep 2003).

8 World resource-limited settings; guidelines for a public health approach. Geneva: World Health Organization, 2002.

9 Ades AE, Davison CF, Holland FJ, Gibb DM, Hudson CN, Nicoll A, et al. Vertically transmitted HIV infection in the British Isles. BMJ 1993;306:1296-9.

10 Tarwater PM, Mellors J, Gore ME, Margolick JB, Phair J, Detels R, et al. Methods to assess population effectiveness of therapies in human immunodeficiency virus incident and prevalent cohorts. Am J Epidemiol 2001;154:675-81.

11 Gortmaker SL, Hughes M, Cervia J, Brady M, Johnson GM, Seage JR 3rd, et al. Effect of combination therapy including protease inhibitors on mortality among children and adolescents infected with HIV-1. $N$ Engl J Med 2001:345:1522-8.

12 De Martino M, Tovo PA, Balducci M, Galli L, Gabiano C, Rezza G, et al. Reduction in mortality with availability of antiretroviral therapy for children with perinatal HIV-1 infection. JAMA 2000;284:190-7.

13 Cascade Collaboration. Determinants of survival following HIV-1 seroconversion after the introduction of HAART Lancet 2003;362:126774.

14 Unlinked Anonymous Surveys Steering Group. Prevalence of HIV and hepatitis infections in the United Kingdom 2001. London: Department of Health, 2002.

15 Kinghorn G. A sexual health and HIV strategy for England. BMJ 2001;323:243-4.

(Accepted 18 August 2003)

\title{
Secondhand effects of alcohol use among university students: computerised survey
}

\author{
John D Langley, Kypros Kypri, Shaun CR Stephenson
}

"Secondhand effects"-negative experiences directly resulting from someone else's drinking-are among the problems associated with heavy drinking. Secondhand effects regularly receive attention from the media, and this probably shapes public opinion on alcohol policies and how individuals behave-for example, avoiding high risk situations-although no empirical studies have examined this. Also, studies of the incidence of secondhand effects are rare. One survey about drinking among college students has found that secondhand effects-including interruptions to study or sleep, having to take care of a drunk student, and being insulted or humiliated-were common.

Many university students in New Zealand often drink hazardously and are therefore a suitable population for studying secondhand effects. ${ }^{2}$ We estimate the incidence of secondhand effects among university students, by the sex, age, and drinking status of the victim.

\section{Participants, methods, and results}

We invited a random sample of 1910 students (aged 16-29 years) at the University of Otago to complete an internet based questionnaire (http://ipru.otago.ac.nz/ ausdemo), and $1564(82 \%)$ responded. ${ }^{3}$ We asked the students which of 11 secondhand effects they had experienced in the previous four weeks (table). ${ }^{1}$ Responses were none, once, two or three times, or at least four times. We assessed whether the respondent was a heavy drinker by asking how often they drank six or more drinks on a single occasion. ${ }^{4}$

We obtained complete data from 1524/1564 (97\%) respondents. Non-heavy drinkers included 62 abstainers and 191 drinkers who consumed fewer than six drinks on any single occasion. Incidence of any secondhand effect increased with the tendency to drink heavily. Logistic regression with adjustment for sex showed that, relative to 16 -19 year olds, 20-24 year olds had similar odds of experiencing at least one secondhand effect (odds ratio 0.80; 95\% confidence interval 0.58 to 1.09 ), and 25-29 year olds were at lower risk $(0.17 ; 0.11$ to 0.26$)$.

A previous study considered only undergraduates in halls of residence or in fraternity or sorority houses-environments linked with excessive drinking. ${ }^{1}$ We found that being pushed, hit, or assaulted was 1.6 times more common (9\% v 15\%), unwanted sexual advances were 1.4 times more common (20\% v 28\%), and damage to property was 1.3 times more common $(15 \%$ v $20 \%)$

\section{Comment}

Secondhand effects due to drinking alcohol are more common among university students than previously thought-for example, a tenth of women and a fifth of men were assaulted at least once in the four weeks
Injury Prevention Research Unit, Department of Preventive and Social Medicine, Dunedin School of Medicine,

University of Otago, Dunedin 9000,

New Zealand

John D Langley professor

Kypros Kypri research fellow

Shaun CR

Stephenson

biostatistician

Correspondence to

J D Langley

johnlangley@ ipru.otago.ac.nz

BMJ 2003;327:1023-4 
Secondhand effects due to alcohol among university students experienced at least once in the four weeks before being asked. Values are numbers (incidence; 95\% confidence interval)

\begin{tabular}{|c|c|c|c|c|c|c|}
\hline \multirow[b]{2}{*}{ Secondhand effect } & \multicolumn{2}{|c|}{ Sex of victim } & \multicolumn{3}{|c|}{ Victim's tendency to drink heavily* } & \multirow[b]{2}{*}{$\begin{array}{c}\text { Total } \\
(\mathrm{n}=1524)\end{array}$} \\
\hline & $\begin{array}{l}\text { Women } \\
(n=881)\end{array}$ & $\begin{array}{c}\text { Men } \\
(n=643)\end{array}$ & $\begin{array}{c}\text { Never } \\
(\mathrm{n}=253)\end{array}$ & $\begin{array}{l}\text { Monthly or less } \\
\quad(n=602)\end{array}$ & $\begin{array}{l}\text { Weekly or more } \\
\quad(n=669)\end{array}$ & \\
\hline Insulted or humiliated & $294(33 ; 30$ to 37$)$ & $221(34 ; 31$ to 38$)$ & $70(28 ; 22$ to 34$)$ & $175(29 ; 25$ to 33$)$ & $270(40 ; 37$ to 44$)$ & $515(34 ; 31$ to 36$)$ \\
\hline Serious argument or quarrel & $148(17 ; 14$ to 19$)$ & $136(21 ; 18$ to 25$)$ & $14(6 ; 3$ to 9$)$ & $81(13 ; 11$ to 16$)$ & $189(28 ; 25$ to 32$)$ & $284(19 ; 17$ to 21$)$ \\
\hline Pushed, hit, or otherwise assaulted & $118(13 ; 11$ to 16$)$ & $114(18 ; 15$ to 21$)$ & $21(8 ; 5$ to 12$)$ & $63(10 ; 8$ to 13$)$ & $148(22 ; 19$ to 25$)$ & $232(15 ; 13$ to 17$)$ \\
\hline Property damaged & $174(20 ; 17$ to 23$)$ & $130(20 ; 17$ to 24$)$ & $43(17 ; 13$ to 22$)$ & $110(18 ; 15$ to 22$)$ & $151(23 ; 19$ to 26$)$ & $304(20 ; 18$ to 22$)$ \\
\hline Had to take care of a drunk student & $370(42 ; 39$ to 45$)$ & $239(37 ; 33$ to 41$)$ & $45(18 ; 13$ to 23$)$ & $227(38 ; 34$ to 42$)$ & $337(50 ; 47$ to 54$)$ & $609(40 ; 37$ to 42$)$ \\
\hline Found vomit in the halls or bathroom & $201(23 ; 20$ to 26$)$ & $173(27 ; 24$ to 31$)$ & $41(16 ; 12$ to 21$)$ & $107(18 ; 15$ to 21$)$ & $226(34 ; 30$ to 38$)$ & $374(25 ; 22$ to 27$)$ \\
\hline Studying or sleep interrupted & $571(65 ; 62$ to 68$)$ & $347(54 ; 50$ to 58$)$ & $135(53 ; 47$ to 60$)$ & $323(54 ; 50$ to 58$)$ & $460(69 ; 65$ to 72$)$ & $918(60 ; 58$ to 63$)$ \\
\hline Unwanted sexual advance & $279(32 ; 29$ to 35$)$ & $151(23 ; 20$ to 27$)$ & $24(9 ; 6$ to 14$)$ & $146(24 ; 21$ to 28$)$ & $260(39 ; 35$ to 43$)$ & $430(28 ; 26$ to 31$)$ \\
\hline Sexual assault or date rape & $8(1 ; 0$ to 2$)$ & $3(0 ; 0$ to 1$)$ & $0(0 ; 0$ to 1$)$ & $3(0 ; 0$ to 1$)$ & $8(1 ; 1$ to 2$)$ & $11(1 ; 0$ to 1$)$ \\
\hline Different crime on campus & $11(1 ; 1$ to 2$)$ & $13(2 ; 1$ to 3$)$ & $4(2 ; 0$ to 4$)$ & 5 (1; 0 to 2$)$ & $15(2 ; 1$ to 4$)$ & $24(2 ; 1$ to 2$)$ \\
\hline Different crime off campus & $26(3 ; 2$ to 4$)$ & $25(4 ; 3$ to 6$)$ & $5(2 ; 1$ to 5$)$ & $20(3 ; 2$ to 5$)$ & $26(4 ; 3$ to 6$)$ & 51 (3; 3 to 4$)$ \\
\hline Any & $752(85 ; 83$ to 88$)$ & $524(81 ; 78$ to 84$)$ & $182(72 ; 66$ to 77$)$ & $476(79 ; 76$ to 82$)$ & 618 (92; 90 to 94$)$ & $1276(84 ; 82$ to 86$)$ \\
\hline
\end{tabular}

${ }^{*}$ Six or more drinks (60 $\mathrm{g}$ ethanol) on one occasion.

preceding our survey, and one fifth of students had their property damaged. ${ }^{1}$ Even non-heavy drinkers experienced several effects, some serious.

Strengths of this study include the random sampling, the high response rate, and using a computerised questionnaire, a method known to increase reporting of high risk behaviour. ${ }^{5}$ Limitations include imprecision-for example, the seriousness of "crimes" is unspecified-reliance on respondents to attribute responsibility for the effect, and our focus on students alone.

The needs of the many non-drinkers and moderate drinkers who are harmed by heavy drinkers should be considered when devising local and national alcohol policies. Universities and colleges should tackle environmental risk factors for hazardous drinking-for example, the availability and promotion of alcohol on and around campus-and should provide screening and intervention services for students with patterns of hazardous drinking.

We thank Dorothy Begg and Margaret Geddis for comments on an earlier version of this paper.
Contributors: JDL got funding for the study, designed the study, analysed the data, and wrote the paper. KK got funding for the study, designed the study, managed and analysed the data, and wrote the paper. SCRS managed and analysed the data and reviewed the paper. KK is guarantor.

Funding: Health Research Council of New Zealand and Alcohol Advisory Council of New Zealand.

Competing interests: None declared.

Ethical approval: University of Otago ethics committee.

1 Wechsler H, Lee JE, Kuo M, Seibring M, Nelson TF, Lee H. Trends in college binge drinking during a period of increased prevention efforts: findings from four Harvard School of Public Health college alcohol study ings from four Harvard School of Public Health collegr

2 Kypri K, Langley JD, McGee R, Saunders JB, Williams S. High prevalence, persistent hazardous drinking in New Zealand tertiary students. Alcoho Alcohol 2002;37:457-64.

3 Kypri K, Gallagher SJ. Incentives to increase participation in an internet survey of alcohol use: a controlled experiment. Alcohol Alcohol 2003;38:437-41.

4 Saunders JB, Aasland OG, Babor TF, de la Fuente JR, Grant M. Development of the alcohol use disorders identification test (AUDIT): WHO collaborative project on early detection of persons with harmful alcohol consumption II. Addiction 1993;88:791-804.

5 Turner CF, Ku L, Rogers SM, Lindberg LD, Pleck JH, Sonenstein FI Adolescent sexual behaviour, drug use, and violence: increased reporting with computer survey technology. Science 1998;280:867-73.

(Accepted 15 July 2003)
St Michael's

Hospital, University of Toronto, 30 Bond Street, Toronto, ON Canada M5B 1W8 Simone N Vigod medical student

Department of Medicine,

St Michael's

Hospital, University

of Toronto

Chaim M Bell

assistant professor

continued over

BMJ 2003;327:1024-5
Respect for the confidentiality of patients' information is a basic principle of ethical and effective medical practice. It ensures individual patients' privacy, and, more broadly, it upholds public perception of the quality of the healthcare system and its professionals. Observational studies have shown that breaches of patients' confidentiality by healthcare professionals occurred in 3\%-7\% of lift rides in hospitals. ${ }^{12}$

Even though most healthcare professionals know the limits of confidentiality well, they have trouble applying them to their behaviour, particularly in hospital lifts where discussions of patients' information may be overheard. ${ }^{3}$ To decrease the risk of compromising patients' confidentiality in public spaces in hospitals, we investigated the number and nature of comments that compromise patient confidentiality in hospital lifts and the reactions of colleagues who witnessed these comments.

\section{Participants, methods, and results}

We instructed medical students in the information privacy policy of St Michael's Hospital, a tertiary care centre in Toronto, Canada. They recorded the date, time, duration, and location of every journey they took in a public lift at St Michael's Hospital during regular hours for two weeks in November 2002. 